\title{
Factors affecting fertilizer use efficiency in dry season paddy production in Makawanpur district, mid hill, Nepal
}

\author{
M Thapa \\ Ministry of Agriculture and Co-operatives, Nepal
}

\begin{abstract}
On-farm assessment of factors defining fertilizer use efficiency (FUE) for dry season paddy production was carried out through field survey and applying a two-step approach. The research was carried out in Makawanpur district, central mid hill, Nepal for the early rice (Chaite season) cropping season 2000. Data on land and land use aspects and yield record were collected through interview and field observation. Data entry, coding and normalization procedure were followed by stepwise regression analysis. In step one, the general regression model for causes of actual yield variations was derived; it included some land and management parameters that satisfactorily explained the variability of actual yields (adjusted $\mathrm{R}^{2}$ of $65 \%$ ). This model was used to calculate the adjusted yields by removing the impacts of non-fertilizer related variables from the actual yield data. In order to evaluate aspects of fertilizer use efficiency (step two), a stepwise regression produced a highly significant (adjusted $R^{2}$ of $45 \%$ ) result. The important factors defining FUE were the relationship between many parameters such as quantity of $1^{\text {st }} \mathrm{N}$ topdressing $\mathrm{x}$ soil $\mathrm{pH}$, basal $\mathrm{N} \times \mathrm{FYM}, 1^{\text {st }} \mathrm{N}$ top dressing $\mathrm{x}$ good drainage condition, $2^{\text {nd }} \mathrm{N}$ top dressing $\mathrm{x}$ insect attack during tillering-flowering stage, $2^{\text {nd }} \mathrm{N}$ topdressing $\mathrm{x}$ soil $\mathrm{pH}$, basal $\mathrm{N} \times$ soil $\mathrm{pH}, \mathrm{FYM} \times$ soil $\mathrm{pH}, 1^{\text {st }} \mathrm{N}$ topdressing $\mathrm{x}$ FYM and $2^{\text {nd }} \mathrm{N}$ topdressing $\mathrm{x}$ zinc deficiency. Thus the study concluded that FUE is one of the critical issues that hindered sustainable paddy production. The timing and quantity of fertilizer especially $\mathrm{N}$ application, source of fertilizer, nutrient content combination, and their interactions with land and land use aspects were crucial elements for getting optimum response to fertilizer.
\end{abstract}

Key words: Fertilizer use efficiency, fertilizer response function, actual yield, adjusted yield

\section{Introduction}

Rice occupies the first place in term of area and total production. In $2008 / 2009$, rice covered $59 \%$ of the total cultivated-cropped area of 1555940 ha, with .production of 4523693 metric tons and the productivity of $2907 \mathrm{~kg} / \mathrm{ha}$ (MoAC, 2009). According to season, rice cultivation is grouped in dry season rice (Chaite rice) and normal rice (main season/ rainy season). Basically the dry season rice is grown in areas where assured irrigation facility is available. The lower foot plains and river valleys are main areas for growing this rice in Nepal. Normally the dry season rice is transplanted in March/April and harvested in July/August. Area and productivity of rice show that from 1961 to 2009, rice yields grew only by 36 $\mathrm{kg} / \mathrm{ha}$ per year. This is a negligible increase of rice yields when compared with the increased NPK use in Nepal. Rice production varies from season to season and from farmer to farmer. By and large, yields are considered too low against yields obtained in experimental stations and by progressive farmers who follow proper husbandry practices of rice production. With the objectives of assessing land factors which affect the efficiency of fertilizer use and evaluating management factors that affect fertilizer use efficiency, a study was done in Makawanpur district, central hill, Nepal. The study area covers approximately 2,426 square kilometres where there were one municipality and 43 Village Development Committees (VDCs). Of the area approximately 61,489 hectares of land was cultivated. Farming was the main occupation in the site and more than $82 \%$ of the population depended on agriculture for their livelihood. 


\section{Fertilizers}

Nepal does not have facilities to manufacture fertilizers. All inorganic fertilizers are imported and often received as aid. Use of fertilizers in Nepal started in 1952 and its increased very rapidly. In Nepal, paddy consumes the largest portion of the total amount of fertilizers sold. Literature shows that every harvest takes away large amounts of nutrients from the soil. There is generally a nutrient uptake of $60-80 \mathrm{~kg} / \mathrm{ha}$ for every tone of grain produced (NARC 1998). Besides, factors like erosion, imbalanced use of fertilizer nutrients and no use of micro-nutrients cause soil nutrient depletion in the country.

\section{Nutrient use efficiency (NUE)}

There has been very little site-specific research on fertilizer use efficiency in Nepal. Many farmers are using fertilizer without rational bases (soil texture, soil $\mathrm{pH}$, organic matter content, and knowledge) which are resulting in low production and over doses leading to high costs, susceptible to diseases and pests as well as environmental pollution. In some cases, unnecessary applications are practiced, whereas plant nutrients essential for efficient crop growth are ignored. Moderate amount of fertilizer can also be used to the good effect if applied at the right time and in the correct manner. NUE is defined as the amount of produce per unit of applied nutrient which given as:

$\mathrm{NUE}=\left(\mathrm{yf}-\mathrm{y}_{0}\right) / \mathrm{N}$

Where, $y f=$ yield from fertilised plot, $\mathrm{y}_{0}=$ yield from unfertilized plot and $\mathrm{N}=$ amounts of nutrient applied.

\section{Fertilizer response function}

Dawe and Dowermann (2000) reported that a fertilizer response function relates yield (output per hectare) to the amount of fertilizer used (input per hectare), holding all other inputs constant. Fertilizer response functions are usually estimated statistically in quadratic form, which allows for the incremental responsiveness of the crop yield decline as larger amounts of fertilizer are used. Such a functional form allows for a finite maximum possible yield (i.e. the yield potential). A hypothetical example of a fertilizer response function would be:

$\mathrm{Y}=2943+19 \mathrm{~N}-0.06 \mathrm{~N}^{2}$

Where, $\mathrm{Y}$ is yield in $\mathrm{kg}$ paddy rice /ha and $\mathrm{N}$ is applied fertilizer in $\mathrm{kg} \mathrm{N} / \mathrm{ha}$.

\section{Methodology}

The study was carried out in Makawanpur district in 2000 during early rice (Chaite rice) season. A total of 85 filed samples were collected from the study site. Data on land and management practices on dry season paddy production and fertilizer management were collected in local units such as Pathi, Muri, Doko, Bhari and then converted to $\mathrm{kg} / \mathrm{ha}$. The impact of fertilizer use efficiency (FUE) was estimated by the described two-step approach. Means and standard deviations are useful for data that follow a normal distribution but are poor descriptors when the distributions are highly skewed or have outliers (Moore and McCabe 1998). 


\section{Results and discussions}

\section{Yield variability}

Anderson-Darling Normality Test (Minitab 13.1) was used to assess the normality of the actual yield data. The field data are thus adequately represented by a normal distribution; they ranged from 1364 to $6000 \mathrm{~kg}$ /ha (average of $3535 \mathrm{~kg} / \mathrm{ha}$ ).

\section{Actual yield regression model}

The first step was to determine a combined relationship between actual rice yields as response variable and other relevant parameters as independent predictors. Of the 124 predictors, the model selected ten independent variables that explained about $65 \%$ (Adjusted $\mathrm{R}^{2}=65 \% ; \mathrm{P}>0.000$ ) of the total yield variability (Table 1). The remaining standard error was $635 \mathrm{~kg} / \mathrm{ha}$.

Table 1. General regression model of causes of actual yields variation

\begin{tabular}{|c|c|c|c|}
\hline Linear multiple regression & \multicolumn{3}{|c|}{$\mathbf{R}^{2}=68.7 \%$} \\
\hline Dependant variable $=$ Rice Yield $(\mathrm{kg} / \mathrm{ha})$ & $\mathrm{N}=85$ & \multicolumn{2}{|c|}{ Adj. $R^{2}=64.5 \%$} \\
\hline Method: Stepwise forward regression & & $S=635$ & \\
\hline 10 steps model & Constant: & 6884 & \\
\hline Predictors & $\mathbf{R}^{2}$ & Coefficient & P-value \\
\hline 1. 1st weeding days after transplanting (DAT) & $23.70 \%$ & -35.64 & 0.001 \\
\hline 2. 1st top dressing Urea $(\mathrm{kg} / \mathrm{ha})$ & $41.10 \%$ & 11.01 & 0.000 \\
\hline 3. Depth of 2 nd ploughing $(\mathrm{cm})$ & $47.90 \%$ & 32.89 & 0.004 \\
\hline 4. If the field has silt loam texture soil & $51.20 \%$ & -586.5 & 0.007 \\
\hline 5. Length of growing period days (seeding to harvest) & $56.90 \%$ & -26.2 & 0.000 \\
\hline 6.If Irrigated every 3 rd day & $60.30 \%$ & 672.9 & 0.017 \\
\hline 7. If the field has clay texture soil & $63.9 \%$ & 623.6 & 0.016 \\
\hline 8. If Irrigated every 5 th day & $66.20 \%$ & -676.8 & 0.019 \\
\hline 9. Date of 1 st ploughing (days from 01/01) & $67.0 \%$ & -7.44 & 0.034 \\
\hline 10. If wheat is grown in rotation ( R-W-R) & $68.7 \%$ & 337.2 & 0.048 \\
\hline
\end{tabular}

\section{Adjusted yield regression model}

Of the ten parameters selected in the above model; only one variable $\left(1^{\text {st }}\right.$ top dressing of urea $)$ was directly related to fertilizer and fertilizer management. In order to remove the impact of non-fertilizer related variables from actual yield data, this factor was dropped when calculating "adjusted yields". The impact of each variable on yield was derived by (i) deducting the original value of an individual variable from the average and multiplying the result by the regression coefficient, and (ii) by adding the result to the actual yield. Summary output of regression analysis of adjusted yields with $1^{\text {st }}$ top dressing of urea has been shown (Table 2).

Where: Ad Yld = Adjusted yield $(\mathrm{kg} / \mathrm{ha})$ and Urea_TD1 $=$ Urea $1^{\text {st }}$ top dressing $(\mathrm{kg} / \mathrm{ha})$

Table 2. Regression analysis of adjusted yield versus urea first top dressing

\begin{tabular}{lllll}
\hline Predictor & \multicolumn{1}{c}{ Coeff. } & SE of Coeff. & $\mathbf{T}$ & $\mathbf{P}$ \\
Constant & 2793.5 & 168.0 & 16.63 & 0.000 \\
Urea_TD1 & 11.012 & 2.298 & 4.79 & 0.000 \\
$\mathrm{~S}=599.9$ & $\mathrm{R}^{2}=21.7 \%$ & $\mathrm{R}^{2}(\operatorname{adj})=20.7 \%$ & \\
\hline
\end{tabular}




\section{Adjusted yield versus fertilizer management}

In order to evaluate individual aspects of nutrient use efficiency, fertilizer related variables were selected from the whole set of parameters. Basically the type, quantity, time and mode of fertilizer application and their interaction with land and management was taken into considerations. Nitrogen application was divided into three variables based on distinct timing of application. The applied dates recorded were 0 day (the day of planting) for basal, 25-35 days after transplanting for $1^{\text {st }}$ top dressing and 45-55 days for $2^{\text {nd }}$ top dressing. A total of 31 variables were included in the trial runs of stepwise regression analysis. Parameters with too few observations or selected ones that were interrelated were identified and removed from the list. The list of variables removed is as follows:

PM_TD = Poultry manure top dressing (only one case)

MP_TD1 $=1^{\text {st }}$ top dressing by Muriate of potash (only one case)

PcAS = Application of Ammonium Sulphate in Previous crop (only two cases)

PcFYM= Previous crop FYM application (related to crop rotation wheat and use of FYM)

AS_TD $=$ Ammonium sulphate $1^{\text {st }}$ and $2^{\text {nd }}$ top dressing

\section{Regression analysis}

Stepwise forward method was applied to determine the factors affecting fertilizer use efficiency. Many regression runs were tried out on a ("trial and error" basis) with eight original fertilizer related variables in combination with other fertilizer management practices and land aspects. The relationship between adjusted yields and interactive predictors was assessed based on the level of significance (P- value) and coefficient of determination (Adjusted $\mathrm{R}^{2}$ ). The model was run with 31 parameters of which nine were accepted by the model; 22 were rejected as being non-significant. Table 3 shows the result of the adjusted yield model estimation; $45 \%$ of the variability (Adj. $\mathrm{R}^{2}$ ) in rice yields was explained by the included nine parameters.The complexity of factors that affect fertilizer response is great and there can be no doubt that they all must be thoroughly understood. The model satisfactorily explains yield variability caused by selected land and land use aspects and their interaction in relation to fertilizer use efficiency (Table 3). The result suggests that soil $\mathrm{pH}$ relates both to the amount of the first nitrogen application rate as to the achieved adjusted yield. Soil $\mathrm{pH}$ from 6.5 to 7.5 showed higher $1^{\text {st }}$ nitrogen top dressing application rates as higher achieved adjusted yields. Similarly, the relationship between rate of phosphorous $\left(\mathrm{P}_{2} \mathrm{O}_{5}\right) \mathrm{kg} / \mathrm{ha}$, soil $\mathrm{pH}$ and adjusted yield suggested that response of phosphorous seems to be higher at soil $\mathrm{pH} 5.5$ to 7.5.

Table 3. Stepwise regression model

\section{Method: Stepwise forward regression}

$\mathrm{R}^{2}=51 \%$

Constant: 2545

Adjusted $\mathrm{R}^{2}=45 \%$

Predictors $\quad \mathrm{R}^{2}$

1. $1^{\text {st }}$ nitrogen top dressing $(\mathrm{kg} / \mathrm{ha}) \mathrm{x}$ Soil $\mathrm{pH}$

$\mathrm{R}^{2} \quad$ Coeff. P-value

2. Basal nitrogen $(\mathrm{kg} / \mathrm{ha}) \times$ Farm Yard Manure $(\mathrm{kg} / \mathrm{ha})$

22.67

27.49

4.01

0.000

3. $1^{\text {st }}$ nitrogen top dressing $(\mathrm{kg} / \mathrm{ha}) \mathrm{x}$ If field has well drained $\quad 33.78$

$-0.0018 \quad 0.000$

$4.2^{\text {nd }}$ nitrogen top dressing $(\mathrm{kg} / \mathrm{ha}) \mathrm{x}$ If insect attack during 37.18

10.50

0.003

tillering and flowering stage

5. $2^{\text {nd }}$ nitrogen top dressing $(\mathrm{kg} / \mathrm{ha}) \times$ Soil $\mathrm{pH}$

$-24.00 \quad 0.007$

6. Basal nitrogen $(\mathrm{kg} / \mathrm{ha}) \mathrm{x}$ Soil $\mathrm{pH}$

$\begin{array}{ll}1.70 & 0.021\end{array}$

7. Farm Yard manure (kg/ha) x Soil $\mathrm{pH}$

41.93

2.11

0.024

8. $1^{\text {st }}$ nitrogen top dressing $(\mathrm{kg} / \mathrm{ha}) \times$ Farm Yard manure $(\mathrm{kg} / \mathrm{ha})$

45.04

0.0114

0.001

9. $2^{\text {nd }}$ nitrogen top dressing $(\mathrm{kg} / \mathrm{ha}) \mathrm{x}$ If zinc deficiency

50.79

$-0.0015 \quad 0.011$

$-45.30 \quad 0.043$ 


\section{General model; selected parameters}

The data analysis discussed in the foregoing suggests that many land use aspects had a significant impact on rice yields. In addition to these, some land attributes such as soil $\mathrm{pH}$, texture and drainage greatly influence dry season paddy production. In the following, only the factors selected in the regression model will be discussed.

\section{Soil texture}

Soil physical properties such as ease of cultivation, nutrient and moisture holding capacity, aeration, drainage and to some extent suitability for cultivation, are strongly correlated with soil texture (FAO 1984). Results of the analyses showed that clay texture had a significant advantage over coarse-textured soil materials as was evident by rice yields. Clay and clay loam soils are best suited for rice production (Manandhar 1999). Clay acts as a storehouse of plant nutrients that are retained by soil and gradually released for uptake as cations $\left(\mathrm{NH}_{4}{ }^{+}, \mathrm{K}^{+}, \mathrm{Mg}^{++}, \mathrm{Ca}^{++}\right.$and others). Clay content influences strongly the nutrients and water-supplying properties of soil (FAO 1984; Bulletin No.9, pp 19). Unlike clay, silt loam texture was found to have a negative impact on yields. This could be associated with low soil-pH; most soils with silt loam texture in the study area are acidic by nature. Nutrient recovery by rice in South Asia is reportedly lowest on silt loam soil (IRRI 1998).

\section{Ploughing, depth and timing}

Tillage is an important activity in agricultural production because it can contribute to a suitable environment for plant growth and has a direct bearing on long-term soil fertility (Smith, 1991). The depth of ploughing depends on the method of ploughing and the physical properties of the soil. Shallow ploughing is associated with oxen drawn indigenous ploughs and deep ploughing with the use of tractors. Shallow ploughing is between 10-15 cm, moderately deep ploughing between $20-25 \mathrm{~cm}$ and deep ploughing is $25-30 \mathrm{~cm}$. Data analysis showed that the depth of the $2^{\text {nd }}$ ploughing (average of $16 \mathrm{~cm}$ ) had a significant impact on rice yields, possibly associated with the incorporation (deep placement) of manure/fertilizer at the time of ploughing. This view is supported by Watanabe and Mitsui (1979), who report that fertilizer nitrogen loss is minimal if broadcast nitrogen fertilizer is incorporated into the furrow slice by crushing soil clods or ploughing it under in wet land rice. Data analysis showed that yields decrease if the date of the first ploughing is postponed. An earlier $1^{\text {st }}$ ploughing fits in a "winter ploughing - fallow" practice, which also controls soil borne insects and diseases and improves soil health. Briggs and Courtney (1994) support this point of view and state that maintenance of the soil phosphorus level is best achieved by ploughing in phosphate fertilizers in autumn. Cropping - fallowing sequences were slightly positively (non-significant) correlated with 'absence of diseases' $(\mathrm{P}=0.736)$. 


\section{Weeding, methods and timing}

Weeds cause reduction of yields because they compete with the crop for light, nutrients and moisture. Due to their varied composition, weeds usually grow faster than rice plants and have an advantage over monocropped rice, absorbing available nutrients earlier and inducing a lack of nutrients for the rice plants. Hand weeding is a common method to control weeds. Farmers who adopted manual weeding in combination with herbicide application $(3 \mathrm{x})$ produced relatively higher yields. The date of the $1^{\text {st }}$ weeding (days after transplanting) showed a significant negative correlation with yield. The average date of $1^{\text {st }}$ weeding in the area was 25 days after transplanting. Delayed first weeding (DAT) is associated with decreased yields. Blackman and Templeman (1938), cited by Moody (1981), found that cereal crops and weeds compete primarily for nitrogen with the most intense competition occurring in the early stage of crop growth. Noda (1973), cited by (Moody 1981), reports that weed competition for nitrogen is most severe during the first half of the rice-growing season.

\section{Irrigation, method and frequency of applications}

A detailed description of irrigation practices in the study area is provided. The most commonly followed method of irrigation is 'controlled flooding'. Canals, streams and seepage are the main sources of irrigation water. The frequency of irrigation has a significant impact on rice yields. Irrigation on every $3^{\text {rd }}$ day gave higher yields than irrigation every $5^{\text {th }}$ day. Watanabe and Mitsui (1979) found that in warmer regions (tropical belts), irrigation should be within three or four days after deep placement of fertilizers; delayed irrigation is associated with high nitrogen loss before irrigation.

\section{Length of the crop growing period}

It is obvious that the length of the crop-growing period is related with the utilization of applied fertilizers in different stages of crop growth. The length of growing season is calculated from the date of seedbed preparation to date of harvesting. The analyses reported here suggest that the length of growing season is negatively correlated with rice yields. It could be that early seeding is associated with old age of seedlings, which has a negative impact on yields. It also seems plausible that delayed harvesting is associated with decrease of yields, e.g. because of heavy rainfall during harvesting. Excess rainfall and delayed harvesting led to lodging and germination of rice grain on the standing crop, in particular with variety CH-45. Sixty-six farmers reported that yields deteriorated because of lodging, excess rain and delayed harvesting.

\section{Crop rotation}

About $83 \%$ of all wheat growers (48x) using a rice -wheat - rice rotation applied FYM to the wheat crop. Step wise multiple regression analysis showed a significant relationship between yields and crop rotation specifications. The favorable effects of rotational cropping on wheat yields could be due to carry-over of plant nutrients from manure and fertilizers applied to a preceding crop. Regmi (2000) confirms this by reporting that phosphorus applied to wheat was found in the 2nd rice (dry season paddy) crop. Similarly, Briggs and Courtney (1994) stated that phosphorus residues persist in the soil, giving a marked carry-over effect from one year to another. 


\section{Rates of fertilizer application}

The average doses of $\mathrm{N}, \mathrm{P}_{2} \mathrm{O}_{5}$ and $\mathrm{K}_{2} \mathrm{O}$ applied in the study area were 99: 22: $38 \mathrm{~kg} /$ ha (organic and inorganic sources). The range of $\mathrm{N}$ application was from $20-248 \mathrm{~kg} / \mathrm{ha}$ and ranges of $\mathrm{P}_{2} \mathrm{O}_{5}$ and $\mathrm{K}_{2} \mathrm{O}$ are $0-101$ and $0-121 \mathrm{~kg} / \mathrm{ha}$ respectively. The average application rates seem to be quite in line with official recommendations, viz. 100: 30: $30 \mathrm{~kg} / \mathrm{ha}$ of $\mathrm{N}: \mathrm{P}_{2} \mathrm{O}_{5}: \mathrm{K}_{2} \mathrm{O}$ (NARC 1999), whereas the quantities of nutrients applied from inorganic fertilizers were 51:43:2 kg of N: $\mathrm{P}_{2} \mathrm{O}_{5}: \mathrm{K}_{2} \mathrm{O} / \mathrm{ha}$. The result of long term fertility trial showed that the rates of fertilizer application (300: 100: $90-\mathrm{N}: \mathrm{P}_{2} \mathrm{O}_{5}: \mathrm{K}_{2} \mathrm{O} \mathrm{kg} / \mathrm{ha}$ or 30 ton $\mathrm{FYM} / \mathrm{ha} /$ year in rice-rice-wheat rotation) was not sufficient to sustain yields in the long term (Regmi, 2000). This suggests the present rates of fertilizer application was less than required. This view is further supported by the fact that nitrogen application in the dry season rice should be $20-60 \mathrm{~kg} N /$ ha higher than in the rainy season (Atanasiu and Samy 1984).

\section{Modes of application}

Since part of the nitrogen applied through ammonium or ammonium- producing fertilizers (urea) is lost through volatilization of ammonia, particularly in calcareous and alkali soils and rice paddies, placement at a few centimeter depth is considered desirable and profitable (Prasad and Power, 2000). The analyses suggest non-significant differences between the encountered methods of basal application. However, application of manure and fertilizer at the time of land preparation produced slightly higher yields, possibly due to moderate deep placement of nitrogenous fertilizer in the reduced soil horizon. Broadcasting on floodwater is common in the area and is likely to result in high losses. The crop recovers only a small fraction of the urea-nitrogen if urea is broadcast at the time of transplanting in flooded rice fields (Driessen and Konijn 1992).

\section{Timing of fertilizer application}

Adapting split application of nitrogen fertilizer can reduce losses of nitrogen and improve the efficiency of uptake by the crop - currently often below 30 percent (FAO Bulletin-9, pp 108). Most often urea is applied in three doses; the quantities of nutrient elements at each application may vary. The quantity of $\mathrm{N}$ applied during $1^{\text {st }}$ top dressing was almost three fold $\left(30 \mathrm{~kg} / \mathrm{ha}\right.$ ) than applied as basal and $2^{\text {nd }}$ top dressing $(10 \mathrm{~kg} / \mathrm{ha})$. The results of data analysis showed that the quantity of the first top dressing of urea $\mathrm{N}(\mathrm{kg} / \mathrm{ha})$ and the time of the first application (days after transplanting) are significantly correlated with rice yield. The quantity of the $2^{\text {nd }}$ top dressing of urea $\mathrm{N}$ showed a non-significant positive correlation with yields.

\section{Sources of nutrients}

Farm Yard Manure (FYM) and Poultry Manure (PM) are organic sources of nutrients that are widely used in the study area. FYM application had a significant positive impact on yields, whereas PM showed a non-significant negative correlation with yields. The latter may be caused by the acidic nature of poultry manure; fresh manure is liable to loss of ammonia by fermentation and also loss of soluble constituents by leaching (FAO, 1984). DAP, Urea, MP and AS are inorganic fertilizers commonly applied to the dry season rice crop. Results of the present analysis suggest that rice yields improve significantly through application of Urea and MP and not when DAP or AS are applied. This could be due to the method and timing of application(s). Often MP is applied as a basal dose after harrowing and before transplanting and urea as a split application. 


\section{Soil pH x nitrogen}

Of the 9 interactive parameters selected, soil-pH multiplied by basal nitrogen, $1^{\text {st }} \mathrm{N}$ top dressing and $2^{\text {nd }} \mathrm{N}$ top dressing showed significant impact on the adjusted yield. Similarly, soil-pH multiplied by FYM application showed significant impact on yields. Data analysis showed that relatively low (4 to 4.5) and relatively high (7.6 to 8.5) soil-pH had lower adjusted rice yields. This result is supported by FAO (1984), saying that soil reaction has a great influence on the availability of plant nutrients, which is generally the highest between $\mathrm{pH} 6.5$ and 7.5. Biological activity is also greatest at intermediate $\mathrm{pH}$ levels (around $\mathrm{pH}$ 7) so that the breakdown of organic matter and release of nitrogen and other nutrients to plants available forms is enhanced. Phosphorus in particular is rendered unavailable in very acid soils because of precipitation as insoluble iron and aluminum phosphates and in high $\mathrm{pH}$ soils by precipitation of insoluble forms of calcium phosphate (FAO 1984). Soil acidity can be corrected by application of basic materials such as limestone. Almost all farmers (83x) did not apply lime. Only two farmers adopted liming; they report increased yields.

\section{FYM x fertilizer nitrogen}

Regression analysis reveals a negative impact of FYM multiplied by nitrogen fertilizers on adjusted yields, possibly associated with the mineralization of FYM which is variable under natural conditions and has various, complex consequences for the nutrient balance of the system. A number of factors need to be taken into account in assessing the effect of organic manures. Briggs and Courtney (1994) reported that as much as two-thirds of the nitrogen and one-half of the phosphorous may not be immediately available i.e., short-term crop responses are often less than anticipated. A further effect of FYM arises from its slow decomposition. Decomposition occurs largely through microbial activity and is accompanied by a marked increase in microbial populations. These raise the demand for nitrogen and may lead to temporary $\mathrm{N}$ deficiencies. For this reason, timing of applications of FYM is critical i.e. ploughing-in of non-composted organic matter should be done at least 10-14 days before starting planting (Atanasiu and Samy 1984). This result is further supported by Driessen and Konijn (1992), who state that only a small fraction of the (broadcast) urea-nitrogen is recovered by flooded rice since the favorable temperature and high oxygen content of the shallow water layer on top of a rice field ensure rapid microbial transformation of the urea$\mathrm{N}$ to nitrate ions $\left(\mathrm{NO}_{3}{ }^{-}\right)$which move with percolating water or by diffusion to puddled soil layers that have become depleted of oxygen by microbes that decompose organic matter. These microbes welcome the incoming nitrate as an oxygen source and reduce it to gaseous $\mathrm{N}_{2}$ and $\mathrm{N}_{2} \mathrm{O}$ that subsequently escape to the atmosphere. Denitrification process under waterlogged conditions is generally accelerated in the presence of readily decomposable organic compounds such as cellulose (Bremner and Shaw, 1958, as cited by Briggs and Courtney, 1994).

\section{Soil drainage $\mathrm{x}$ nitrogen}

Results of the final regression analysis showed a significant relationship between adjusted yield and soil drainage status multiplied by first $\mathrm{N}$ top dressing. Soil physical properties such as aeration, drainage and other favorable soil conditions (suitability for multiple cropping) influence the efficiency of applied fertilizer-elements. This result is indirectly supported by FAO, 1983 (Bulletin No. 6; pp 26) saying that N losses are particularly severe in waterlogged soils (increased availability to crops associated with higher losses); the extent of the compounded losses commonly ranges from 10 to $45 \%$ of all $\mathrm{N}$ applied with fertilizer. Similarly, poor drainage can induce large denitrification losses (Prasad and Power 2000). Cultivation on acid sulfate soils is hampered by toxic levels of soluble iron and aluminum, as well as by low phosphorus availability (IFPRI, 1995). This notion is supported by the fact that denitrification is 
essentially an anaerobic process resulting from the microbial extraction of oxygen from nitrates, and is most common under waterlogged conditions (Briggs and Courtney, 1994).

\section{Zinc deficiency $x$ nitrogen}

Regression analyses showed that a significant negative relationship exists between adjusted yields and the associated effect of Zinc deficiency and $2^{\text {nd }} \mathrm{N}$ top dressing. According to FAO 1984, multiple deficiencies can occur where soil supplies of several nutrients are inadequate. The relationship between crop yield and fertilizer application is also sensitive to nutrient interactions, so that responses depend in part on limitations imposed by other nutrients (Briggs and Courtney, 1994). Zinc deficiency is associated with calcareous, alkali and peat soils that are wet or water logged most of the year; deficiencies are more severe when high rates of nitrogen are applied (IRRI 1983).

\section{Insect attack $x$ nitrogen}

The analyses showed a negative impact on adjusted yields by the associated effect of insects attack (during tillering and flowering stages of crop growth) and $2^{\text {nd }}$ nitrogen top dressing. Heavy infestation of insects especially rice bug and leaf folder might have reduced the uptake of applied nitrogen. This result can be supported by the fact that fertilizer response (basically $\mathrm{N}$ ) varies from stage to stage of crop growth due to interaction with stochastic disturbances such as weather and insects and disease infestation (IRRI 1985; IRPS No. 115). Losses due to insects reported appear to be considerably larger ( $810 \mathrm{~kg} / \mathrm{ha})$ in Nepal than in most other countries (Upadhyaya 1996 as cited by Herdt 2000).

\section{References}

Adhikari C, B Adhikari, NP Rajbhandari, M Hooper, HK Upreti, BK Gyawali, NK Rajbhandari and PR Hobbs. 1999. Wheat and Rice in the Mid-Hills of Nepal. Nepal.

Atanasiu, N and J Samy, 1984. RICE: Effective use of fertilizers. Zurich / Switzerland.

Beets, CW. 1990. Raising and sustaining productivity of Smallholder Farming Systems in the Tropics. Holland.

Borlaug, N. 1994. Agricultural Research for Sustainable Development. Testimony before US House of representatives committee on agriculture.

Briggs, DJ and FM Courtney. 1994. Agriculture and Environment. The physical geography of temperate agricultural systems. England. Published by Longman Singapore.

CBS (Central Bureau of Statistics), 1999. Statistical yearbook of Nepal. Kathmandu.

DADO, 1999 (District Agriculture Development Office), Yearly progress report (Nepali version). Makawanpur district Nepal. Kathmandu.

Dawe, D and A Dobermann. 2000. Defining productivity and yield. http://www.cgiar.org/irri/Produ.PDF. June 16, 2000 .

de Bie, CAJM.2000. Comparative Performance Analysis of Agro-Ecosystems. Ph D Thesis, Wageningen Agricultural University, The Netherlands.

Driessen, PM and NT Konijn.1992. Land Use Systems analysis. Wageningen Agricultural University, Department of Soil Science and Geology, The Netherland.

FAO, 1976, 1984, 1987 and 1998. A framework for land evaluation. Soils Bulletin 32; Fertilizer and plant nutrition. Bulletin No. 9 and Maximizing Fertilizer Use Efficiency. Bulletin No.6; Fertilizer Strategies; Terminology for integrated resource planning and management. Compiled and edited by K Choudhary and LJM Jansen. FAO, Rome.

Harington, LW, S Fujisaka, PR Hobbs, C Adhikari, GS Giri and K Cassaday. 1992. Rice-Wheat cropping systems in Rupandehi District of the Nepal Terai. Diagnostic survey of farmers' practices and problems and needs for further research. Kathmandu.

Herdt, RW. 2000. Rockfeller foundation priorities for rice biotechnology research in 1995 and beyond.http:/www.isnar.org/irri/abstract.htm 
Hobbs, PR and C, Adhikari, 2000. The importance of Rice wheat systems for food security in Nepal. http://www.cimmyt.mx/Research/N down loaded on 21 June 2009. .

www.apps.fao.org/cgi-bin/nph-db.pl. FAOSTAT, 2000. Subset agriculture (25 May, 2000).

IFPRI, 1995. Gruhn, PFGoleti, and RN Roy. Proceedings of the IFPRI/FAO workshop on plant nutrient management, food security, and sustainable agriculture: The future through 2020. Viterbo, Italy.

IRRI. 1983. Field problems of tropical rice. Philippines.

IRRI. 1998. Irrigated rice ecosystem. IR3 Improving the productivity and sustainability of rice-wheat systems. Project summary and highlights, Philippines.

Linquist, BP Sengxua, A Whitbread, J Schiller and P Lathvialayvong. 1997. Evaluating nutrient deficiencies and management strategies for lowland rice in Lao PDR. IRRI abstract.

Manandhar, DN. 1999. Rice Production Technology (Nepali Version). Nepal Agricultural Research Council. Kathmandu.

MoA/N, 2000. Fertilizer unit, Ministry of Agriculture, Nepal http://www.fadinap.org/nepal/stat.html

MoAC, 2008/2009. Statistical Information on Nepalese Agriculture. Government of Nepal, Ministry of Agriculture and Co-operatives, Singha Durbar Kathmandu, Nepal.

Moody, K. 1981. Weed fertilizer interactions in rice. IRRI Research papers series No. 68.

Moore, DS and George P McCabe.1998. Introduction to the practice of statistics. Purdue University. 
Murayama, N. 1979. The importance of nitrogen for rice production. In: Nitrogen and rice. IRRI, Phillippines.

NARC (Nepal Agricultural Research Council). 1988. NARC, Nepal

NARC, 1998. Proceedings of first national workshop on long-term soil fertility experiments. 11-13 August 1998. Soil Science Division. Khumaltar, Nepal.

Nkamleu, GB and A A Adesinia. 2000. Determinants of chemical input use in peri-urban lowland systems: bivariate probit analysis in Cameroon. ELSEVIER, Agricultural systems 63 (2000) 111-121.

Pandey, GP. 1998. Rainfed agriculture in Nepal. http://www.panasia.org.sg./nepalnet/agriculture/Nepal.html

Prasad, R and JF Power, 2000. Soil fertility management for sustainable agriculture.

Rana, DS.1997. Guidelines for seed quality control and minimum seed certification standards. FAO of the United Nation.

Regmi, AP.1997. Effects of long term application of mineral fertilizers and manure on rice-rice-wheat system. Proceedings of the Rice-wheat research, End of project workshop. Kathmandu Nepal

Regmi, AP.2000. Effects of long term application of mineral fertilizers and manure on rice-rice-wheat system. . http://www.cimmyt.mx/Research/N.

Smith, J and G Umali. 1985. Production risks and optimal fertilizer rates: An application of the random coefficient model. IRRI (IRPS No. 115).

Smith, R. 1991. Conservation Tillage Research. In tillage, past and future, CIMMYT FSR Networkshop. Report No.22.

Watanabe, I and S Mitsui. 1979. Denitrification loss of fertilizer nitrogen in paddy soils. Its recognition and impact. IRRI Research papers series (IRPS) No. 37. 